\author{
I. A. Taraban, D. V. Oklei, \\ V. O. Prasol, S. O. Beresnyev, \\ N. I. Dmuhovskyi
}

State Institution «Zaitsev V. T. Institute of General and Urgent Surgery of National Academy of Medical Sciences of Ukraine»

\section{CATHETER-DIRECTED THROMBOLYSIS AS A METHOD OF CHOICE IN THE TREATMENT OF ACUTE THROMBOSIS OF DEEP VEINS OF THE LOWER EXTREMITIES}

Summary. Introduction. Acute thrombosis of deep veins (DVT) of the lower extremities is a pathology that requires immediate treatment, but most thrombolytics do not work effectively, except for catheter-directed thrombolysis.

Research aim. Rationalization of DVT treatment, determination of the catheter thrombolysis method as the most effective way to eliminate proximal thrombosis of deep veins.

The analysis was based on the results of the treatment by different thrombolytic drugs the patients with the given pathology.

Results and discussion. According to the analysis the most effective method of DVT treatment is catheter-guided administration of streptokinase, because streptokinase is the most effective anticoagulant, and its local action on the mass of the thrombus allows for complete elimination of the thrombus in a relatively short time without the counter allergic reaction to the infusion of streptokinase.

Conclusions. Catheter-directed infusion of streptokinase as a method of treatment of acute thrombosis of the lower extremities has significantly better treatment results compared to other methods of treatment of this pathology.

Key words: catheter-directed thrombolysis, acute thrombosis of deep veins of the lower extremities, thrombolytic therapy.

\section{Introduction}

Venous thromboembolic complications (VTE), including deep vein thrombosis (DVT) and pulmonary embolism (PE), is a hot problem in modern medicine due to one of the frequent causes of mortality and invalidation [1]. According to epidemiological studies, the incidence of deep vein thrombosis in the general population is $56-160$ cases per 100000 of population every year and reaches 500 cases per 100000 of males in older age groups with a stable tendency for increasing [1, 2]. At the same time, the incidence of PE (the most dangerous complication of DVT with lethal outcome according to autopsy data) is 50 cases per 100,000 patients per year [3]. According to other investigations, lethality from DVT in inferior vena cava system, complicated by PE, is from 5 to $20 \%$ [4]. They confirm that the main source of pulmonary artery embolism is lower extremity DVT. Lower extremity DVT and $\mathrm{PE}$ are now considered as two aspects of the same pathological process - venous thromboembolism (VTE), which causes high morbidity and mortality $[1,2,4]$.

When the proximal segment of the lower extremity veins is involved in the thrombotic process, the inversion of the valve apparatus of the veins occurs, resulting in venous dysfunction and, in the long term, the development of post-thrombotic disease (PTD). Despite the availability of a large arsenal of effective anticoagulants and the use of modern regi- mens antithrombotic therapy, $30-75 \%$ of patients in the long-term have PTC of varying severity, and $10-40 \%$ of them suffer from marked edema of the lower extremities, chronic pain and/ or trophic ulcers that lead to severe signs of invalidity [2, 4]. So, in the structure of primary innovalidity as a result of lower extremity vein diseases, the results of suffered VTEU are $77.4 \%$ of cases [1, 2]. Therefore, the tactics of management of patients with proximal DVT, as before, remains a subject of active discussion both in our country and abroad.

Today thrombolytic therapy is a method of alternative treatment of acute thrombosis in the inferior vena cava system, as stated in the recommendations of the American College of Thoracic Physicians [4, 5].

The first drug used for thrombolysis in DVT was streptokinase $[1,5]$. Streptokinase is a highly purified enzyme produced by cultivation of $\beta$-hemolytic group C Streptococcus. It has fibrinolytic activity. When combined with plasminogen, streptokinase forms a complex that activates the transfer of blood plasminogen or blood thrombus into plasma. Plasmin dissolve thrombus and also leads to degradation of fibrinogen and other plasma proteins. After the end of the infusion the hyperfibrinolytic effect of streptokinase is observed only for several years. However, the increase in thrombin time can last up to 24 years due to a one-time decrease in fibrinogen level and an increase in the number of circulating products of fibrin and fibrinogen degradation. TS 
of the streptokinase-plasminogen complex, which activates plasmin, is close to $23 \mathrm{hr}$. Since streptokinase is a weak streptococcal antigen, it is partially inactivated by anti-streptococcal antibodies, which are always present in the blood. The state of fibrinolysis is achieved only when an extra quantity of streptokinase is administered, which is necessary for neutralization of antibodies and the onset of active streptokinase penetration into the thrombus.

Another thrombolytic is urokinase, an enzyme activator of plasminogen, which is derived from the cultures of human cells of kidney. It shows fibrinolytic action, activates glu- and lysplasminogens, converts them into plasma, which causes enzymatic destruction of fibrin. Lysis of fibrin leads to disintegration of the thrombus components and its disintegration into other fragments, which are carried by the blood flow or are filled on the spot with plasma. Created products of fibrinogen degradation contribute to hypocoagulation, block the aggregation of erythrocytes and thrombocytes, reduce blood consistency. After parenteral administration the hypocoagulation disorders are detected after 3-6 years. Efficacy increases with repeated administration in combination with heparin at low doses

Before establishing of therapy for setting effective doses it needs to choose activity of plasminogen and antithrombin III, thrombin time and fibrinogen content in the blood. When plasminogen depletion in the blood (severe stenotic atherosclerosis, recurrent thromboembolism, myocardial infarction, fatty disease, hyperlipidemia) the use of high-dose urokinase with a long course and combining with fresh plasma and plasminogen preparations is recommended. During pregnancy therapy may not be effective due to the presence of high levels of natural inhibitors of urokinase in the blood. After intravenous administration it connects with plasma proteins and is inactivated by proteases. The drug does not cause important allergic reactions $[4,6]$.

Tissue plasminogen activator (TAP) is also a physiological activator of the fibrinolytic system, has less systemic activity than streptokinase, but does not have antigenicity. Low molecular weight and similarity to fibrin allow TAP to penetrate into the thrombus more than other thrombolytic drugs and activate fibrin-linked plasminogen. The main difference between the tissue activator of plasminogen and streptokinase and urokinase is that it acts directly in the thrombotic masses. This provides more advantage of effective intravenous lysis of thrombotic masses. In this case there should be no fibrinogenolysis with serious hemorrhages. The advantage of the drug is also short duration of therapy (from 2 to 3 years) with the same therapeutic effect as with other fibrinolysis activators. However, after a certain time of using the drug it was found that it can also cause hemorrhagic complications, as well as incompetent lysis of "old" thrombi, which are organized [4]. Taking into consideration the above , we can state that currently the ideal fibrinolytic drug is absent in the arsenal of physicians [6].

If we evaluate available thrombolytics for clinicians according to the level of safety and efficacy, then, in our opinion, they are located in the following way: streptokinase, urokinase, tissue activator of plasminogen.

Despite their disadvantages, all of them are widely used in modern phlebology practice. When considering the choice of thrombolytic drugs, not only their efficiency but also their cost should be taken into account.

In a review of data from 6 clinical studies, systemic thrombolysis was 3,7 times more effective than heparin. In a combined analysis of 13 randomized studies, only $4 \%$ of patients treated with heparin achieved significant or complete lysis, 45 patients after systemic use of streptokinase. Despite the fact that systemic thrombolytic therapy (according to clinical studies) is effective compared to $\mathrm{UFH}$, the risk of bleeding when using this method increases by 3-4 times [4-6]. Studies have shown that systemic use of thrombolytic drugs in widespread occlusive thrombosis of deep veins is unlikely to be effective due to the lack of contact area of the drug with thrombotic masses in conditions of disturbed regionary hemodynamics $[4,7]$.

This fact played a crucial role in the fact that more and more often regionary thrombolysis was used instead of systemic thrombolytic drug administration. The fact that regionary thrombolytic therapy (RTLT) is more effective compared to UFH has been proven in clinical studies. In RTLT, the physician is able to reduce the dose of the drug, thus delivering the active substance directly to the thrombosis site, thus ensuring faster and more efficient thrombolysis and, most importantly, reducing the risk of bleeding $[6,8]$.

Quality and efficiency of thrombolysis depend on many factors. An important factor is the "age" of the thrombus [4], it is considered that thrombolytics administration during 3-10 days after the development of deep vein thrombosis is the most effective [6]. Localization, width of thrombosis, as well as the type of thrombolytics and the method of its administration play an important role in the efficiency of thrombolytic therapy [7, 9].

Further investigations in this area led to the development of catheter- directed thrombolysis (CDT) method, the introduction of which into clinical practice made it possible to restore deep vein permeability in $80 \%$ of patients without an increase of the number of bleeding $[8,10]$.

Direct catheter techniques using streptokinase to treat proximal DVT achieved complete thrombus lysis in $72 \%$ of patients for concomitant reduction of symptoms. Selective delivery of thrombolytic agent allows achieving high concentration of the 
substance within the thrombus, which would be impossible due to its systemic use $[3,11]$. The achieved effect of blood coagulant lysis is due to the effect of active plasma that is produced as a result of activation of fibrin-related plasminogen. Injection of thrombolytic drug directly into the coagulant allows to protect activators of plasminogen from neutralizing action of antiplasmins, circulating in the blood. Catheter-assisted injection of plasminogen activators directly into the clot accelerates the treatment process and ensures successful treatment of DVT in the majority of cases. The use of an accelerated regimen reduces the total dose and duration of plasminogen activator infusions, so reducing the number of hemorrhagic complications.
Direct catheter thrombolysis should be used during DVT treatment in active patients with low risk of bleeding, especially in ileofemoral segment, because the risk of PTD appearance is higher than in distal DVT (stage B) [11, 12].

Conclusions. The use of such method as CDT enables to fully or partially restore the vessel opening, to save the function of venous valve apparatus, using minimal doses of thrombolytics which are injected directly into the middle of the thrombus, thus minimizing hemorrhagic complications. Therefore, catheter-assisted thrombolysis is more and more often used as a method of choice for treatment of patients with proximal phlebothrombosis [4, 6, 9-12].

\section{REFERENCES}

1. ISTH Steering Committee for World Thrombosis Day. Thrombosis: a major contributor to global disease burden. Thromb. Res.2014;134:931-8.

2. Heit JA. Epidemiology of venous thromboembolism. Nat. Rev. Cardiol.2015; 12:464-74.

3. Mahan CE, Barco S, Spyropoulos AC. Cost-of-illness model for venous thromboembolism. Thromb. Res.2016;145:130-2.

4. Kearon C, Akl EA, Comerota AJ, et al. Antithrombotic therapy for VTE disease: antithrombotic therapy and prevention of thrombosis, 9th ed.: American College of Chest Physicians Evidence- Based Clinical Practice Guidelines. Chest. 2012;141:419-940.

5. Meissner MH, Gloviczki P, Comerota AJ, et al. Early thrombus removal strategies for acute deep venous thrombosis: clinical practice guidelines of the Society for Vascular Surgery and the American Venous Forum.J.Vasc. Surg. - 2012;55:1449-62.

6. Comerota AJ. Catheter-directed thrombolysis for iliofemoral deep vein thrombosis: helpful or hurtful? Expert Rev Hematol. 2015;8(2):131-3.

7. Haig Y, Enden T, Slagsvold CE, et al. Determinants of early and long-term efficacy of catheter-directed throm- bolysis in proximal deep vein thrombosis.J. Vasc. Interv. Radiol. 2013;24:17-24.

8. Bжkgaard N, Klitfod L, Jwrgensen M. Should catheter-directed thrombolysis be monitored? Phlebology. 2016;31:5-10.

9. Xue GH, Huang XZ, Ye M, Zhang JW, Zhang BG. Catheter-directed thrombolysis and stenting in the treatment of iliac vein compression syndrome with acute iliofemoral deep vein thrombosis: outcome and follow-up. Ann.Vasc. Surg. 2014;28(4):957-63.

10. Lu T, Loh TM, El-Sayed HF, et al. Single-center retrospective review of ultrasound-accelerated versus traditional catheter-directed thrombolysis for acute lower extremity deep venous thrombosis. Vascular.2017;25(5):525-32.

11. Lin M, Hsieh JCF, Hanif M, et al. Evaluation of thrombolysis using tissue plasminogen activator in lower extremity deep venous thrombosis with concomitant femoral-popliteal venous segment involvement. J.Vasc.Surg.Ven.Lymph. Disord. 2017;5(5):613-20.

12. Gombert A, Gombert R, Barbati ME. Patency rate and quality of life after ultrasound-accelerated catheter-directed thrombolysis for deep vein thrombosis. Phlebology.2017;33:251-60. 
КАТЕТЕР-КЕРОВАНИЙ ТРОМБОЛІЗИС ЯК МЕТОД ВИБОРУ ПРИ ЛІКУВАННІ ГОСТРОГО ТРОМБОЗУ ГЛИБОКИХ ВЕН НИЖНІХ КІНЦІВОК

\section{I. А. Тарабан, Д. В. Оклей, В. О. Прасол, С. О. Береснєв, Н. І. Дмуховский}

Реферат. Bcmyn. Гострий тромбоз глибоких вен (ТГВ) нижніх кінцівок - патологія, котра потребує своєчасного лікування, однак більшість тромболітичних засобів діють неефективно, окрім катетер-керованого тромболізу.

Мета дослідження. Раціоналізація лікування ТГВ, визначення катетер-тромболізисного методу як найбільш дієвого стосовно усунення проксимальних тромбозів глибоких вен.

Результати. За даними аналізу найбільш ефективним методом лікування ТГВ є використання катетер-керованого введення стрептокінази, бо саме вона $є$ найбільш дієвим антикоагулянтом, а локальна її дія на масу тромбу дозволяє повністю зруйнувати останній за доволі короткий час без виникнення зустрічної алергічної реакції на введення стрептокінази.

Висновок. Катетер-керований метод введення стрептокінази, як метод лікування гострого тромбозу нижніх кінцівок має набагато кращі результати лікування, порівняно з іншими методами лікування даної патології.

Ключові слова: катетер-керований тромболізис, гострий тромбоз глибоких вен нижніх кінцівок, тромболітична терапія.

Реферат. Введение. Острый тромбоз глубоких вен (ТГВ) нижних конечностей - патология, которая требует своевременного лечения, однако большинство тромболитических средств действуют неэффективно, кроме катетер- управляемого тромболизиса.

Цель исследования. Рационализация лечения ТГВ, определение катетер-тромболизисного метода как наиболее действенного по устранению проксимальных тромбозов глубоких вен.

Результаты. По данным анализа наиболее эффективным методом лечения ТГВ является использование катетер-управляемого введения стрептокиназы, потому что именно она является наиболее действенным антикоагулянтом, а локальное ее действие на массу тромба позволяет полностью разрушить последний за довольно короткое время без возникновения встречной аллергической реакции на инфузию стрептокиназы.

Bыводы. Катетер-управляемый метод введения стрептокиназы, как метод лечения острого тромбоза нижних конечностей имеет гораздо лучшие результаты лечения по сравнению с другими методами лечения данной патологии.

Ключевые слова: катетер-управляемый тромболизис, острый тромбоз глубоких вен нижних конечностей, тромболитическая терапия. 